\title{
Os Bairros Sociais Vistos por si Mesmos Actores, Imagens Públicas e Identidades
}

\author{
Alda Gonçalves * \\ Teresa Costa Pinto ${ }^{* *}$
}

\begin{abstract}
$\mathrm{R}$ Lesumo: Este artigo resulta de uma pesquisa realizada no âmbito do Observatório da Habitação ( $6^{\mathrm{a}}$ fase), por encomenda da Câmara Municipal de Lisboa ao CET, desde 1992 e desenvolvido de forma faseada no tempo. Esta fase foi realizada entre Outubro de 1998 e Janeiro de $2001^{1}$ e tinha como objectivo genérico aprofundar o conhecimento dos processos de estruturação de identidades e imagens públicas negativas em bairros sociais, já objecto de estudo do Observatório em fases anteriores.

Através de uma pesquisa exploratória e uma abordagem qualitativa em três dos bairros em estudo, pretendia-se identificar os actores reconhecidos pela comunidade local como produtores das imagens públicas negativas dos bairros, bem como avaliar os efeitos das suas práticas sobre as dinâmicas sociais de cada um dos bairros. $O$ presente artigo pretende ilustrar alguns dos elementos que a pesquisa tornou perceptível: a droga, as conflitualidades e os bandos de jovens são categorias centrais de discursos heterogéneos de actores residentes que, de formas diversas, apreendem, (re)constroem e representam, para si, as imagens públicas que reconhecem negativas dos seus bairros para, de seguida, as exteriorizarem e a elas reagirem, imagens profundamente enraizadas que os realojamentos não souberam ou não puderam apagar. Estes bairros actuam como verdadeiros contextos de estigmatização e os entrevistados, responsáveis activos pela produção dessas imagens, são actores cujas oportunidades, projectos e identidades se encontram irremediavelmente ligadas às imagens públicas negativas dos seus contextos residenciais.
\end{abstract}

Palavras chave: imagens públicas; identidades; estigma; estratégias identitárias; droga/toxicodependência; conflitualidades.

\section{Introdução}

Complementar ao artigo com o mesmo título genérico, publicado no $\mathrm{n}^{\bullet} \mathrm{l}$ desta revista, este pretende apresentar alguns dos resultados a $2 .^{\mathrm{a}}$ linha de pesquisa ${ }^{2}$, efectuada no contexto da 6. ${ }^{\text {a }}$ fase do Observatório da Habitação ${ }^{3}$.

Importa começar por referir que esta linha de pesquisa foi também sugerida pelos resultados obtidos com o estudo anterior (fase 5 do Observatório da Habitação) que apontavam a visibilidade do fenómeno do tráfico e do consumo de droga, a conflitualidade endémica, resultante dos conflitos pessoais e de vizinhança, bem como a presença de minorias étnicas, entendidos pelos actores sociais residentes, como os principais factores que se encontravam na base da estruturação das imagens negativas dos respectivos bairros em estudo.

Por sua vez, estas imagens negativas condicionavam as possibilidades de apropriação do espaço público e identidades positivas face

\footnotetext{
* Socióloga. Técnica do IDS. Investigadora do CET.

** Assistente de Sociologia do ISCTE. Investigadora do CET.

1 A primeira linha de pesquisa que se efectuou neste contexto inspirøu um artigo, publicado sob o mesmo título genérico no $1 .^{\bullet}$ número desta Revista. Este artigo complementa o anterior, permitindo uma aproximação ao conteúdo da segunda linha de pesquisa que decorreu nesta $6 .^{a}$ Fase.

${ }^{2}$ Cujo relatório se designa Processos de Constituição de Imagens Públicas, Dinâmicas de Conflitualidade e (In)segurança e no qual colaboraram também Artemisa Delgado e Teresa Isabel Oliveira.

${ }^{3}$ As duas pesquisas desta $6 .{ }^{a}$ Fase sobre alguns bairros sociais de Lisboa, foram realizadas por uma equipa do Centro de Estudos Territoriais, em 1999, coordenadas por Teresa Costa Pinto, por solicitação da Câmara Municipal de Lisboa.
} 
aos bairros, comprometendo significativamente os objectivos de reestruturação dos modos de vida e as condições de inserção social dos residentes.

Tendo como pano de fundo estas preocupações, a pesquisa obedeceu aos seguintes objectivos:

- Identificar e conhecer os actores reconhecidos pela comunidade local como os produtores das imagens públicas negativas dos bairros, através a) da identificação das diferentes formas de lidar com o estigma e b) da identificação das diferentes formas como estes actores constroem as suas estratégias em resposta ao estigma de que são alvo.

- Avaliar os efeitos das suas práticas sobre as dinâmicas sociais de cada um dos bairros.

A utilização de uma metodologia qualitativa e compreensiva foi considerada como a mais adequada às especificidades do campo de análise em questão - os actores produtores de imagens negativas pareciam assumir maior visibilidade e exigir maior atenção: o Horta Nova, o Casal dos Machados e o Boavista.

Foram realizadas entrevistas semidirectivas (35 no total) com estatutos diversos e que foram objecto de tratamento e análise diferenciada a: informadores privilegiados, junto dos quais foram feitas entrevistas exploratórias (sobretudo, a técnicos dos Gabinetes Locais) e a actores responsabilizados pela produção das imagens negativas dos bairros (18, uma das quais colectiva). Estas últimas conferiram especificidade a esta linha de pesquisa, justamente por permitir dar voz aos que são apontados e, por sua vez, reconhecem contribuir para a produção e difusão das más imagens do bairro.

A recolha de informação foi efectuada na base de um guião que permitia, por um lado, dar conta das especificidades que contribuíam para a reprodução de uma imagem pública negativa,

$$
\begin{array}{cl} 
& \text { Toxicodependentes } \\
& \text { Traficantes } \\
\text { Tipologia de Actores } & \text { Famílias desestruturadas } \\
\text { Produtores de Imagens } & \text { Famílias numerosas } \\
\text { Públicas } & \text { Indivíduos com problemas de alcoolismo } \\
\text { (entrevistados) } & \text { Indivíduos com problemas do foro psicológico } \\
& \text { Minorias étnicas } \\
& \text { Mães solteiras } \\
& \text { Bandos de jovens }
\end{array}
$$

negativas - e à necessidade de obter resultados em intensividade.

A escolha dos bairros teve em conta as seguintes etapas:

- Recolha de informação capaz de dar conta da formação e trajectória de cada bairro em termos de composição social e demografia.

- Reuniões com técnicos dos Gabinetes Locais, no sentido de perceber quais os principais traços característicos e as vulnerabilidades existentes em cada bairro.

- Construção de uma tipologia de actores reconhecidos e apontados como responsáveis pela produção de imagens negativas dos bairros -, submetida à classificação dos técnicos dos Gabinetes Locais, quanto à percepção sobre as contribuições dos actores identificados para as imagens públicas negativas e para as dinâmicas de conflitualidade e de insegurança.

$\mathrm{O}$ universo de estudo incidiu sobre os três bairros sociais com maior nível de informação a cruzar e, simultaneamente, aqueles em que os problemas de imagens e dinâmicas sociais para dinâmicas de conflitualidade e, por outro lado, identificar famílias e indivíduos relacionados com tais problemáticas e que se constituíssem como "alvos de estigma" por parte dos outros residentes.

As entrevistas foram depois sujeitas à análise de conteúdo: temática, tipológica e categorial.

\section{Ambiguidade Face aos Bairros: entre sentimentos de pertença e de rejeição}

Sabendo que os Bairros em estudo (Horta Nova, Casal dos Machados e Boavista), quer por experimentarem processos de realojamento mais ou menos recentes e faseados, quer pela dinâmica da estrutura urbana na qual se inserem, se encontram em processo contínuo de transformação das suas dinâmicas sociais e urbanísticas, tornava-se importante compreender quais os factores que assumiam maior relevo na produção de imagens públicas (positivas e/ou negativas) dos bairros. 
Os espaços residenciais são simultaneamente públicos e privados, constituindo uma mediação fundamental entre as acções e comportamentos individuais e as expressões diversas que aí assumem as estruturas socioculturais, induzindo e sendo palco de interacções e apropriações que lhes traçam perfis característicos. São lugares nos quais as ambiguidades, a diversidade de representações sociais e os sentimentos de pertença/rejeição, quando legíveis, se tornam referentes classificatórios específicos, sobretudo no caso de bairros sociais como estes, cujos processos de realojamento parecem não ter sido capazes de inflectir a segregação socioeconómica e espacial, que anteriormente os atingia.

Neste contexto, torna-se perceptível que os espaços residenciais, enquanto centros da vida social quotidiana, constituem um dos referentes identitários, mais fortemente afectado (positiva ou negativamente) pela percepção das trajectórias dos bairros e pelas vivências dos processos de realojamento.

Em relação ao tipo de realojamentos, o bairro Casal dos Machados distingue-se do Horta Nova e do Boavista, na medida em que, enquanto nestes se observou um "realojamento local", no primeiro tem dominado um "realojamento disperso", com população proveniente de locais muito diversificados e faseado no tempo (os primeiros realojamentos efectuaram-se entre 1993 e 1994 e os últimos entre 1997 e 1998). A estrutura urbanística deste bairro evidencia-o no contexto da malha envolvente, devido aos seus "altos prédios cor-de-rosa", tal como é percebido pelos "olhos comuns". Este crescimento em altura, a par com a densidade e diversidade populacional existente, tem tido consequências significativas nas relações e nas dinâmicas sociais, percebidas e expressas de forma diferenciada pelos seus moradores, condicionando inclusivamente as percepções dos bairros e os sentimentos de pertença.

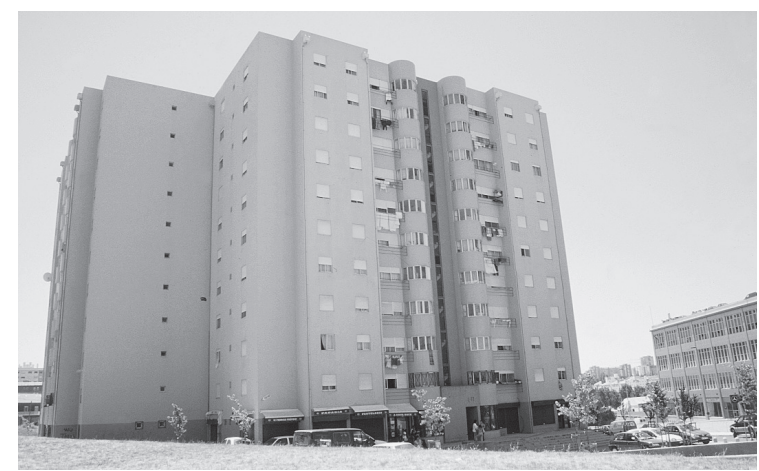

Casal dos Machados. Foto de Alda Gonçalves
No bairro Horta Nova, pelo facto de se tratar de um cenário pós-realojamento já estabilizado, com moradores de longa data (os tempos de residência dos entrevistados variam entre "toda a vida" e 8 a 9 anos), permitiu que o realojamento fosse avaliado pelos próprios actores que viveram o processo, destacando os efeitos duradouros que a mudança de cenário residencial produziu. A construção do Bairro Novo foi claramente percebida como o acontecimento de maior importância na transformação das relações sociais locais.

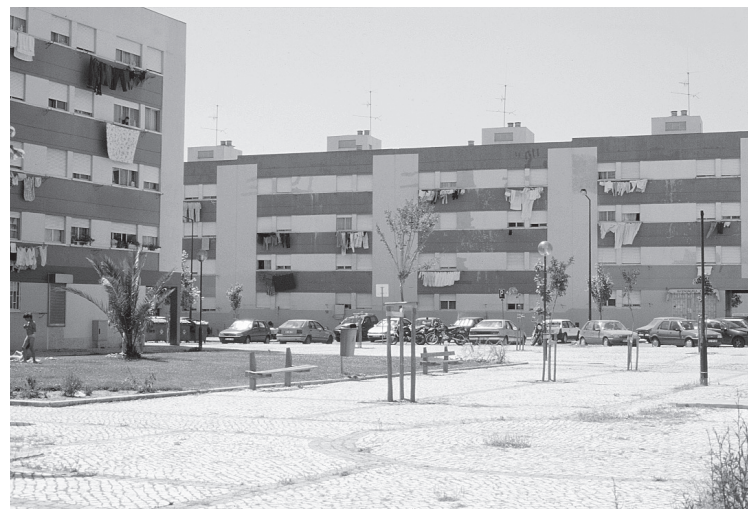

Horta Nova. Foto de Alda Gonçalves

O bairro Boavista, por seu lado, foi mandado construir pela CML na década de 40, enquanto bairro provisório de Habitação Social enquadrado num plano de construção de Casas para famílias pobres para substituição de barracas de madeira e lata que existiam já em grande número na periferia de Lisboa.

Os realojamentos definitivos em modelos de habitação do tipo construção em altura vieram a acontecer já nos anos 80 ( $1^{\mathrm{a}}$ fase). Na década de 1990 ( $2^{\text {a }}$ fase) foram atribuídos mais 195 fogos entre 1990 e 1993/94 em edifícios que registam uma grande continuidade urbanística com os anterior. A partir de 1995 teve início a $3^{\text {a }}$ fase do realojamento a qual se caracterizou por um investimento na estética do bairro.

Genericamente, o perfil social desta população realojada remete para alguns tipos de exclusão social. É uma população que, pela frágil posição no sistema socioeconómico e baixas qualificações profissionais e escolares, ocupa uma posição na estrutura e na hierarquia de prestígio social que a impede de assumir protagonismo na escolha do espaço residencial, sendo, assim, relegada para espaços sociais e simbolicamente desvalorizados que se situam "no reverso da urbanidade" (Gonçalves, 1996: 27). 
A pobreza e a exclusão social, na medida em que se expressa territorialmente por via do próprio dinamismo dos processos de segregação urbana e das formas de apropriação que a estrutura social vai fazendo do espaço, tende a ser algo visível assimilando-se ao próprio espaço, tornando-o num lugar socialmente desvalorizado. "Neste contexto trata-se de perceber se o espaço surge como um elemento de ligação entre a pertença ao Bairro e o desenvolvimento de características de solidariedade e/ou de oposição ou se pelo contrário ele é apenas o lugar de vivência dessas formas de solidariedade e oposição, situando a sua explicação, fora do contexto espacial." (Teixeira, 1995:27)

Nesta sequência, foi possível encontrar actores com posicionamentos heterogéneos em relação à trajectória e aos processos de requalificação territorial dos bairros que se reflectiram nas suas vivências, assumindo um maior relevo no contexto da pesquisa, por se saber contribuírem activamente para a produção de imagens negativas dos seus bairros.

A análise de conteúdo permitiu observar como um dos traços comuns aos três bairros, uma percepção do impacto dos realojamentos que destaca os efeitos sobre as dinâmicas sociais, nomeadamente a desestruturação das relações sociais locais de sentido comunitário que se considera terem caracterizado os bairros velhos. É a visão crítica dominante no discurso dos entrevistados, com predomínio das mulheres que mais estruturam o seu quotidiano em torno do espaço doméstico. A "visão feminina" que enfatiza as dinâmicas de vizinhança é, simultaneamente, uma visão saudosista, pois a coesão do "bairro velho" aparece empolada para tornar mais evidentes as dimensões da conflitualidade e do isolamento que, segundo estes actores, caracteriza o quadro actual das relações sociais locais.

Observem-se os seguintes extractos de entrevistas:

"Muita, muita diferença (do bairro antigo para o bairro novo) o bairro velho era mais unido. As pessoas eram muito mais amigas, preocupavam-se mais com o Ser Humano do que neste bairro."

(E5, Toxicodependente em recuperação, residente com a família no bairro desde os 8 anos, Angolana - Horta Nova)

"Eu gostava mais do bairro velho, quando eles moravam nesse bairro (...) eram muito amigos uns dos outros. Lá, eram amigos, se estivessem mal uns ajudavam-se uns aos outros", sei lá era um ambiente diferente, como se não houvesse droga. (...) "Era muito diferente, mesmo a malta nova por aquele tempo que eu vivi, mesmo antes de vir morar para estas casas esquisitas, que isto estragou mais os jovens."

(E9, Mulher, 33 anos, companheira de toxicodependente e pequeno dealer, reside no bairro há 8-9 anos - Horta Nova)

Um outro traço comum aos três bairros, é o facto de alguns dos actores entrevistados expressarem um sentimento de satisfação face à mudança residencial, centrado claramente na melhoria das condições de vida que os realojamentos proporcionaram, representando, simultaneamente, uma efectiva melhoria das condições de habitabilidade e uma mobilidade ascendente em termos de estatuto residencial, promovendo sentimentos de integração nos padrões urbanos de habitar.

Observem-se os seguintes fragmentos discursivos:

"A casa aqui é melhor, no bairro do relógio eram casas pré-fabricadas de madeira, no Inverno chovia lá dentro, como em todas as casas de lá, chovia, havia baratas, ratos, mesmo daqueles! (...)".

(E18 - Mãe: cabo-verdiana, imigrante, 62 anos. Filha: 23 anos, estudante - Casal dos Machados)

"Sempre é melhor, morava numa barraca, deram-nos um prédio, já é melhor" (...) bairros sociais destes (como o Casal dos Machados) não se comparam com barracas e miséria, podridão, não têm esgotos, saneamento. Eu no relógio não tomava banho todos os dias, aqui tomo. Não tomava, não era falta de vontade era porque não tinha possibilidades de tomar banho todos os dias (...) aqui não, temos gás canalizado, temos tudo".

(E17 - jovens de origem africana, 22 e 24 anos, ambos trabalham - Casal dos Machados)

Na mesma sequência, alguns actores enfatizaram o gosto pela casa, tal como os anteriores, mas manifestaram um desgosto pelo seu bairro, caracterizado por um sentimento de frustração face ao contexto residencial, acompanhado por uma atitude de minimização dos ganhos obtidos com o realojamento. $\mathrm{Na}$ base deste sentimento de frustração, estão representações sociais de sentido negativo sobre os bairros, as quais remetem para diferentes aspectos como a interiorização imagens públicas desvalorizadas e o descontenta- 
mento com a natureza das relações sociais locais. Relativamente a esta última dimensão, alguns dos entrevistados destacaram, por um lado, as dinâmicas de conflitualidade presentes nas relações de vizinhança geradoras do "mau ambiente do bairro" e, por outro lado, a diluição das relações sociais de sentido comunitário, decorrentes ora de estratégias de evitamento de relações tendencialmente conflituais, ora do impacto causado pela elevada densidade populacional geradora de anonimato nas dinâmicas sociais.

Eis o que se pode observar através das seguintes ilustrações:

"Eu estava ali a viver no Relógio, mas aqui é tudo a mesma coisa, é tudo o mesmo ambiente. Só o que há aqui a mais é as casas, agora um tipo saindo da porta da rua para fora é tal e qual estar outra vez ali".

(E11 - casal, família cigana, vendedores ambulantes - Casal dos Machados)

"Eu não pedi para vir para cá. Não gosto do ambiente do bairro, pronto, temos de ir para onde nos mandam (...) se eu pudesse comprar uma casa para viver melhor, para viver num sítio mais sossegado e onde não haja [má] fama, se eu pudesse comprar, comprava (...)".

P. [Fale-me de um aspecto positivo que essa mudança terá trazido]

R: "Olha, a casa, a casa não é má, não, é boa. Eu gosto da casa, não desgosto da casa mas se tivesse poder... se tivesse dinheiro comprava uma casa e saía daqui".

(E15 - Mulher, 37 anos, cabo-verdiana, empregada de limpeza - Casal dos Machados)

Outros, evidenciaram ainda uma postura crítica face ao impacto da nova estrutura espacial, isto é, das habitações unifamiliares para os prédios, espaços de gestão colectiva, destacando, por um lado, a perda de um sentimento de maior liberdade e ausência de constrangimentos na apropriação do espaço que a anterior organização espacial de habitações unifamiliares permitia e, por outro, uma maior tendência ao centramento do quotidiano em torno da casa (o apartamento simboliza a privatização do espaço), provocando consequentemente a diluição das sociabilidades de vizinhança antes predominantes nos bairros. Hoje, o isolamento dos agregados familiares e, sobretudo, dos seus elementos mais idosos domina o quotidiano:

"Dantes estava-se mais à vontade, agora há mais deveres assim com os outros (...) prontos, já não é aquele tão à vontade como era dantes (....) uma gajo aqui nos prédios tem mais condições melhores, a casa é maior, um quarto para cada um, tem mais privacidade, 2 casas de banho, esses pequenos pormenores"

(E1, jovem nascido no bairro, etnia africana - Boavista)

"Dantes saías à rua e davas logo de caras com o teu vizinho. Aqui (no prédio) não, tens de descer as escadas, tens de ir de elevador, tens de descer, chegar lá em baixo, e quando a pessoa chega lá em baixo já a pessoa se foi embora (...) lá em baixo era diferente, a gente saía ao portão... era só uma ruazinha" referindo-se aos avós:

"agora não, é raro saírem [irem ao café] cá do prédio, comprei uma máquina [de tirar café] $e$ tudo por causa deles. É diferente, não sou só eu que sinto, há mais pessoas".

Boavista)

(E3 - Mulher, 16 anos, Nascida no Bairro -

A seguinte ilustração coloca a tónica do impacto do realojamento exclusivamente nas alterações em termos de composição social $e$ étnica, relacionando a entrada de novos residentes com a "deterioração" social do bairro:

"Nas casas velhas como havia antigamente, não havia raça negra nenhuma (...) uns vieram lá da Boavista, outros vieram de Chelas, da Musgueira, outros vieram das Galinheiras, da Charneca, está a ver, de todo o lado, eu penso assim, Portugal é um caixote e é a mesma coisa com o bairro da Horta Nova, foi um caixote nessa altura [do realojamento] que acolheu essas pessoas que não devia acolher que não deviam ter casa aqui."

(E6, Homem, 32 anos reside no bairro desde os 6 anos - Horta Nova)

Específicas dos entrevistados do Horta Nova são as representações que enfatizam a visibilidade crescente da droga e as formas de segregação a que são sujeitos os toxicodependentes. Neste quadro de "endurecimento" das relações sociais, são as famílias que, pelas suas trajectórias e modos de vida, se encontram em situação de maior vulnerabilidade económica e social que são alvo de estigmatização. É também neste contexto, em que o acesso a um novo estatuto residencial vem despoletar estratégias de distinção social, que a droga ganha uma visibilidade acrescida e uma conotação negativa, como se pode em seguida observar:

"E vê-se mais (a droga)... lá está: nota-se mais a droga porque no bairro antigo não é que 
não houvesse, havia, só que tinha muito refúgio "prontos" de se meterem. Aquilo era (...) tinha aquelas barracas todas não se via tanto "toxicoindependente" porque às tantas consumiam às escondidas de toda a gente. Havia jovens que consumiam, e que ainda consomem, muitos têm 30 e tal anos e ainda consomem, muitos estão metidos na droga há 10 e 15 e 20 anos. Temos aí um rapaz que está metido já há 22 anos. $E$, portanto, só vieram a descobrir que eles eram "toxicoindependentes" aqui no bairro. Porquê Porque entretanto as casas..., eles não se metem dentro dos prédios, são escorraçados dos prédios, porque as pessoas estragam os elevadores $e$ entretanto não os deixam lá entrar (...). É tudo feito na rua normalmente, e assim nota-se mais o coiso da "toxicoindependência".

(E5, Mulher, 28 anos, reside no bairro desde os 8 anos, angolana - Horta Nova)

Por último, alguns actores de forma mais radicalizada, enunciam um sentimento de total rejeição em relação ao ambiente do bairro. Nessa radicalização de sentimentos, chegam a negar qualquer vantagem do realojamento. A casa anterior (reconhecida como "mais feia" e "mais pequena") permanece, contudo, como um referente identitário positivo que a melhoria das condições habitacionais não conseguiu suplantar, como o demonstram as seguintes reacções:

"Acho que era melhor (a casa anterior), era pequena, baixinha, de pedra e tijolo, não era um pré-fabricado (...) a minha mãe pagava renda, era da Câmara, tinha tudo, luz, dois quartos...".

(E14 - jovens de origem africana, 16 e 14 anos, desempregado e estudante, pertencem a grupo de jovens responsabilizados pela má imagem - Casal dos Machados)

"Gostava mais da outra casa, gostava mais da outra casa porque foi lá que vivi lá a minha vida toda, [se pudesse voltar] voltava... desde que tivesse a mesma casa, a mesma, não interessa se é pequena, se é feia... [podes descrevê-la] pequena, confortável, não faltava nada [mas como é que era feita, quantos quartos] tinha 3 quartos, a água era de graça (...) não chovia lá dentro, era cómodo".

(E16 - jovem, origem africana, desempregado, pertence a grupo de jovens responsabilizados pela má imagem - Casal dos Machados)

"Eu achava melhor do que aqui [o bairro anterior] porque as pessoas quando mudaram para aqui ficaram todas ricas [ricas?] porque lá, as pessoas faziam barulho e ninguém dizia nada, agora uma pessoa está ali na relva a brincar, a jogar e dizem logo: isso não pode ser, vieram para aqui têm que mudar".

(E14 - jovens de origem africana, 16 e 14 anos, desempregado e estudante, pertencem a grupo de jovens responsabilizados pela má imagem - Casal dos Machados)

Estes últimos actores possuem uma reputação que os associa à pequena delinquência e ao consumo de droga - contorno de uma imagem pública negativa do bairro e de um sentimento de insegurança face a este - e que os envolve frequentemente em dinâmicas de conflitualidade intergeracional no interior do seu bairro, ajudando a configurar os contornos da imagem pública negativa do mesmo e a despoletar sentimentos de insegurança.

Em síntese, e de acordo com o resultado da análise categorial (cf. Esquema 1), que em seguida se apresenta, a forma como o impacto dos realojamentos é avaliado pelos actores entrevistados não se faz à margem, nem das distinções de género nem dos tempos de residência, isto é, do enraizamento da população nos bairros.

As duas categorias fundamentais em torno das quais giram as outras, demonstrando uma complexidade de factores entrecruzados nas percepções em relação às trajectórias dos bairros, são a requalificação residencial e a transformação das relações sociais. É em função do impacto que elas provocaram nas experiências de realojamento vividas pelos actores entrevistados, que se definem os sentimentos (expressos) de pertença e/ou rejeição face aos novos contextos residenciais.

Os bairros anteriores surgem constantemente como elementos de comparação com os quais alguns dos entrevistados demonstraram ainda sentimentos de identificação e interferem nos projectos de vida, incluindo os residenciais, condicionando a forma como os realojamentos a eles se adequaram ou não.

A diversidade de experiências de realojamento dos que já viviam no interior do bairro, nomeadamente no caso do bairro da Boavista e a dos novos residentes vindos de fora tiveram consequências ao nível dos sentimentos de pertença ou de rejeição ao bairro. No primeiro caso, houve quem considerasse o processo de requalificação territorial como um mero "embelezamento do contexto residencial", enquanto os entrevistados que viveram a experiência do realojamento foram mais longe referindo-se ao impacto que a nova estrutura espacial teve ao nível das relações sociais locais. 
No segundo caso, salientaram a importância da percepção de uma imagem pública negativa e de como esta jogou um papel importante numa atitude inicial de fechamento face ao novo contexto de residência.

Neste sentido, a percepção e interiorização de imagens públicas negativas levou, em alguns casos, a processos de rejeição do ambiente dos bairros, processos esses em relação estreita com a insatisfação residencial que, como se observou, contribuiram para gerar formas de apropriação dos espaços que não só reforçaram essa negatividade das imagens públicas (como por exemplo os actos de vandalismo) como contribuiram para gerar e/ou reforçar dinâmicas de conflitualidade. Práticas muitas vezes reconhecidas e apontadas a actores específicos e por alguns deles assumidas.

$\mathrm{Na}$ transformação das relações sociais, foram referidos factores como a percepção de alterações nas relações de vizinhança, quer no sentido de uma diluição das sociabilidades, quer do aumento de rivalidades associadas à "privatização" dos modos de vida que a nova casa veio possibilitar. Destacaram-se ainda alterações na composição social e étnica da população induzida pela entrada de novos residentes e a percepção das diferentes trajectórias socioprofissionais que ocorreram no interior de uma população com características de relativa homogeneidade social.

Por seu lado, a percepção da evolução do fenómeno da droga ou o aumento da sua visibilidade em alguns espaços públicos (segregados) apareceu, muitas vezes, entendida como factor de desestruturação das dinâmicas sociais e familiares locais, capaz de se sobrepor ou de tornar invisível a própria requalificação residencial. De salientar, no entanto, que para os toxicodependentes entrevistados, a droga não é percepcionada como um factor conducente a essa desestruturação mas como algo preexistente já nos bairros velhos e que o desenvolvimento dessas dinâmicas sociais simultaneamente de distinção e estigmatização, vieram tornar mais visíveis, com repercussões negativas na imagem pública dos bairros.

Esquema 1 - Categorias Intervenientes na Percepção da Trajectória dos Bairros - Impacto dos Realojamentos

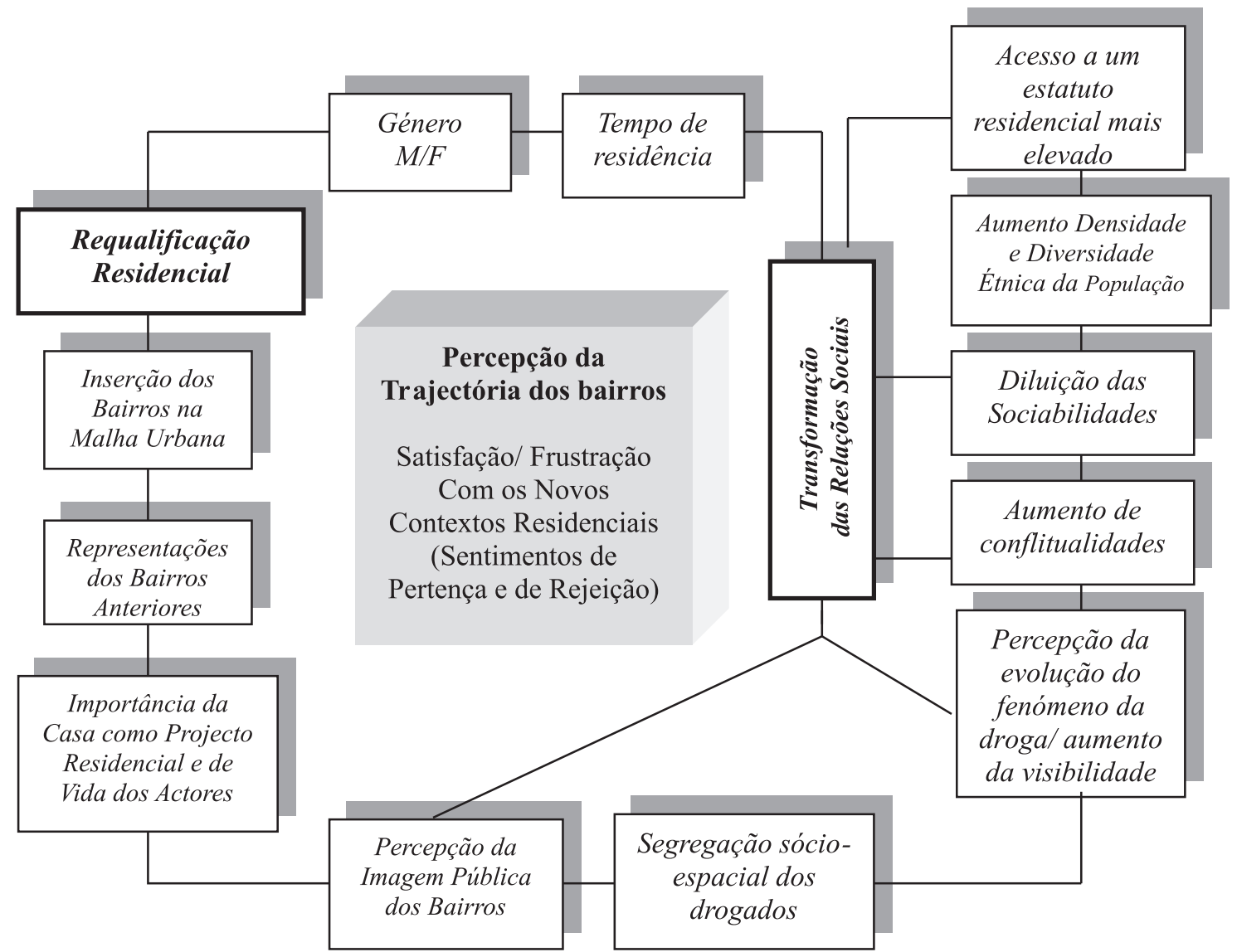


O esquema anterior indiciava já que a percepção da trajectória dos bairros se afigurava determinante na definição e expressão de sentimentos de pertença e/ou de rejeição face aos novos contextos residenciais e o Esquema 2, demonstra justamente, a complexidade de dimensões que se jogam nessa construção afectiva e identitária.

Observaram-se representações sobre os bairros como espaços sociais e simbólicos, enquadradores das relações sociais dos actores e do sentido que estes lhes atribuem e, simultaneamente, como estruturas espaciais com impactos a nível das dinâmicas sociais.

Os actores demonstram ainda uma percepção dos bairros como espaços urbanizados remetendo para as suas condições de infra-estruturação e, consequentemente, para a identificação de carências que, em conjunto com outros atributos, contribuem significativamente para a estigmatização de cada um deles. Por exemplo, a denúncia de carências do bairro em termos de equipamentos recreativos vem circunscrever o lazer ao contexto da casa (a um lazer interior, ouvir música, ver TV, sozinho ou com amigos) e, eventualmente, à conversa nocturna junto ao lotes de residência:

"Aqui neste bairro é que há poucas coisas para se fazer. Precisava de muita coisa este bairro. As pessoas quando querem fazer alguma coisa nunca fazem dentro do bairro, quando se querem divertir têm de ir..

[costumas frequentar cafés?]

"De vez em quando, mas não é cá no bairro, quando vou a Algés, por exemplo, vou trabalhar, vou sempre um bocado mais cedo, vamos ao café mais os meus amigos, estamos lá um bocado (...) as pessoas quando querem fazer alguma coisa nunca fazem dentro do bairro. Quando se querem divertir têm que ir lá para fora, ao Colombo, ao Amoreiras, ao Fonte Nova..."

(E4 - Homem, 20 anos, novo residente há ano e meio no bairro - Boavista)

A análise das entrevistas permitiu dar conta de uma considerável ambivalência de sentimentos em relação aos bairros em análise. A visibilidade da droga e a centralidade que possui no quotidiano de parte destes actores entrevistados são factores que contribuem para essa ambivalência, por vezes latente, outras vezes manifesta.

Nesta sequência, os bairros aparecem, no caso de alguns actores, representados simultaneamente como referentes identitários positivos $e$ negativos. Enquanto referentes positivos desta- cam as boas recordações que possuem: o "bairro da infância", da "escola primária", das "brincadeiras na rua". No reverso, enquanto referentes desvalorizadores, ressalta a percepção das dinâmicas (de conflitualidade) presentes nos bairros, a presença da droga e o impacto destas duas dimensões a nível da (re)produção de imagens exteriores negativas e estigmatizantes estigmatizadoras. O desejo de abandonar os bairros, no futuro, é uma característica comum a estes actores. Observe-se, por exemplo:

"Cresci sempre aqui [neste bairro e nesta casa] foi aqui que ganhei as minhas amizades, na rua; tenho a minha melhor amiga que é a Sandra, tenho a Alexandra também (...). "Nós [refere-se ao seu núcleo familiar] estamos a pedir transferência para outro bairro social, não estamos a pedir transferência porque estamos em más condições (de habitabilidade)... queremos outra zona (...) não queremos ir nem para o Casal Ventoso nem para Chelas. Se houver um bairro social calmo, que deve haver, sei lá, se nos derem alternativas nós vamos escolher"

(E2, mulher, nascida no bairro, vive apenas com o pai e não possui mais família no bairro Boavista)

"Eu gosto do bairro, fui criada aqui, gosto, toda a gente tem bom relacionamento comigo, nunca fui pessoa de arranjar problemas com ninguém, nunca me chateei com ninguém, toda a gente gosta de mim (...), toda a gente gosta de mim, toda a gente me aconselhava — as pessoas mais velhas - que era para eu deixar a droga, eu gosto de estar aqui neste bairro, só que o clima entre jovens é que não é bom.... (...) é um bairro em que os jovens estão quase todos metidos na droga... todos os rapazes que andaram comigo, pronto que eu considero meus amigos andaram comigo na escola, foram criados comigo no bairro... eu conheço bem eles (os drogados) $e$ todas as pessoas me conhecem, é as pessoas que nós lidamos todos os dias, e uma pessoa que saia do mundo da droga que viva neste bairro só tem uma maneira: ou sair daqui, ou arranjar um emprego e sair do bairro, só chegar a casa à noite"

(E5 - Toxicodependente em recuperação, 28 anos, etnia negra - Horta Nova)

Sentimentos de uma mais clara expressão de rejeição aos bairros são também visíveis, pela relação vinculativa à toxicodependência, mas a ambivalência "sente-se" na dupla dependência face ao bairro e à droga. Nestes casos, os bairros são entendidos como "desertos" de sentimentos 
positivos, pois todos os laços afectivos anteriores foram quebrados:

"Este bairro não vale nada, não interessa a ninguém (...) [no bairro] sinto-me sozinha, sem ninguém, sem ajudas... já tentei sair [da droga] depois volto para aqui, estou sozinha e pronto, meto-me outra vez"

(E7 - Mulher, Toxicodependente, 28 anos, portadora de HIV, prostituta, ruptura familiar Horta Nova)

"Estou farto do bairro até dizer chega, só me traz é más recordações, todos os dias a droga, todos os dias a mesma vida, levantar-me ressacado, ir matar a ressaca, vem, vou-me orientar outra vez, vou-me drogar, levanto-me, pimba, outra vez droga (...) já vivi 2 anos no Casal Ventoso mas depois começaram a mandar as barracas abaixo e tive que me vir embora, estava sempre a ser escorraçado: "Não és daqui, vens para aqui, já não chega os que cá estão, vai-te embora daqui pá...

[Intervenção da entrevistadora: ao menos aqui tinha família, já não o podiam escorraçar?]

Não é pela família, ao menos aqui nasci aqui, ninguém me podia mandar embora daqui, não era pela família porque a minha mãe não apoia o facto de eu estar a dormir ali"

(E10 - Homem, 23 anos, Toxicodependente, nascido no bairro, ruptura familiar - Horta Nova)

Embora com menor expressão, foi possível ainda encontrar alguns actores manifestando sentimentos de pertença e adesões afectivas ao seu bairro, considerando-o como suporte do desenvolvimento das relações de amizade que se foram consolidando e que se intensificam actualmente em práticas colectivas de apropriação dos espaços, como pode observar-se no seguinte fragmento discursivo:

Esquema 2 - Categorias Intervenientes na Construção de Diferentes Sentimentos Face aos Bairros

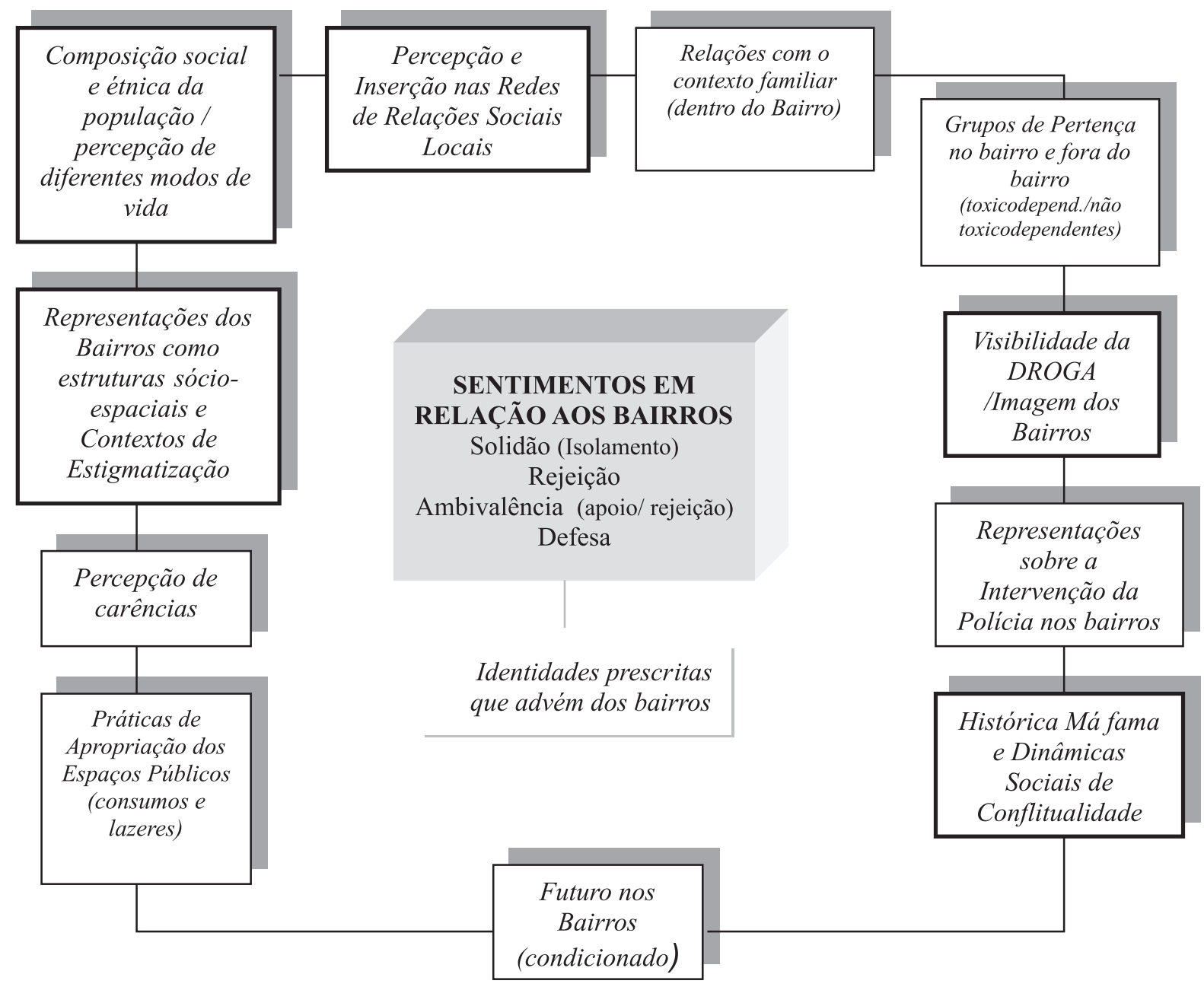


"[o bairro] é um sítio onde um gajo se sente seguro (...) é o nosso pombal (...) temos aqui os nossos amigos, que são os amigos de infância"

(...) eu não tenho zona, eu ando pelo bairro todo, todas as noites, o bairro todo"

(E1, jovem nascido no bairro - Boavista)

Em síntese, o que mais ênfase detém nas representações e adesões afectivas aos bairros são as dinâmicas das relações sociais dominadas pelas conflitualidades (nas quais muitos dos entrevistados se encontram envolvidos) e pela omnipresença da droga, bem como nas relações que estas possuem com as imagens públicas negativas, já que boa parte dos entrevistados têm, pelas suas práticas de apropriação dos espaços, pelos seus comportamentos e atitudes e pelos seus modos de vida, uma responsabilidade acrescida, na produção dessas imagens estigmatizadas e estigmatizantes.

\section{Percepção das Imagens Públicas: a construção do estigma}

As conflitualidades, a insegurança, a visibilidade do fenómeno da droga e a existência de grupos ou bandos de jovens, são as três dimensões fundamentais reconhecidas como responsáveis pela produção de imagens públicas negativas, quer pelos interlocutores privilegiados, quer pelos seus produtores, que se destacaram na análise das entrevistas, embora o relevo atribuído a cada uma delas seja diferente em cada um dos bairros.

Estas questões possuem reflexos importantes ao nível das identidades residenciais, componente forte das identidades sociais e relevam, no caso dos actores implicados na sua produção, de "estratégias identitárias" muitas vezes reactivas e nem sempre facilmente decifráveis nos contextos de estigmatização em que estes actores se movem.

As dimensões de conflitualidade e os sentimentos de insegurança são transversais aos três bairros em análise assumindo, contudo, uma centralidade significativa no discurso dos entrevistados do Casal dos Machados.

Os interlocutores privilegiados, nomeadamente técnicos a trabalharem nos bairros distiguem dois tipos de dimensões relevantes na produção de imagens públicas dos bairros:

- Dimensões sociais, como a concentração de população social e economicamente desfavorecida à qual atribuem modos de vida marginais que assentam essencialmente no tráfico e no consumo de drogas; população cuja composição social é rejuvenescida e de etnias diversas, conotada como produtora de efeitos negativos na apropriação dos espaços públicos e nas dinâmicas sociais aí geradas; dão conta de actos de delinquência, como a violência, agressão, assaltos e vandalização do edificado.

- Dimensões urbanísticas como a inserção dos bairros na malha urbana e variáveis arquitectónicas que remetem para a estética do bairro.

Os moradores, por seu lado, referem-se essencialmente às dimensões sociais que se cruzam na construção duma imagem pública que é reconhecida, pela maioria dos entrevistados, como negativa e portadora de um estigma difícil de erradicar.

$\mathrm{Um}$ posicionamento de reconhecimento inequívoco da imagem pública negativa, define-se por uma consciencialização da exterioridade do atributo "Má Fama" do bairro ou de "Bairro de Bandidos". Os contributos para estas imagens estereotipadas fazem-se por via relacional, especialmente pelas disposições orientadas para a desconfiança, o medo e a insegurança patentes nas relações anónimas que se estabelecem no interior do bairro, classificando e colando rótulos negativos a certos actores, com base em meras impressões, (aparências físicas, etc.). Tais classificações propiciam contextos de conflitualidade ao nível das relações sociais.

A presença policial parece fazer eco, nesses contextos, da relação que se estabelece entre os jovens, nomeadamente de origem negro-africana e os adultos (sobretudo de etnia branca). No centro dos conflitos encontram-se as formas de apropriação do espaço, as sociabilidades juvenis e a droga, com fortes impactos na reprodução daquela imagem:

[Qual é a imagem que tu achas que as pessoas de fora têm do bairro?]:"Bandidos". (...) Quando eu vim morar para aqui foi o que os meus primos disseram: "Ah! Agora vais morar para um bairro de bandidos, vais-te tornar um bandido". (...) este bairro antes era mesmo... tinha má fama antes de vir morar para aqui. Os gajos de Chelas eles moravam aqui. Moravam no Cambodja. Este bairro antes era muito perigoso. Aqueles que nos chamam de bandidos (...) põem fama num gajo (...)Ouvem-nos a fazer barulho, às vezes veêm um cigarro aceso pensam que é droga: "ai polícia estão aqui uns gajos a fumar droga!"

(E16 - Jovem (M), etnia negra, 19 anos, residência anterior C. Grande, já não estuda, não trabalha - Casal dos Machados) 


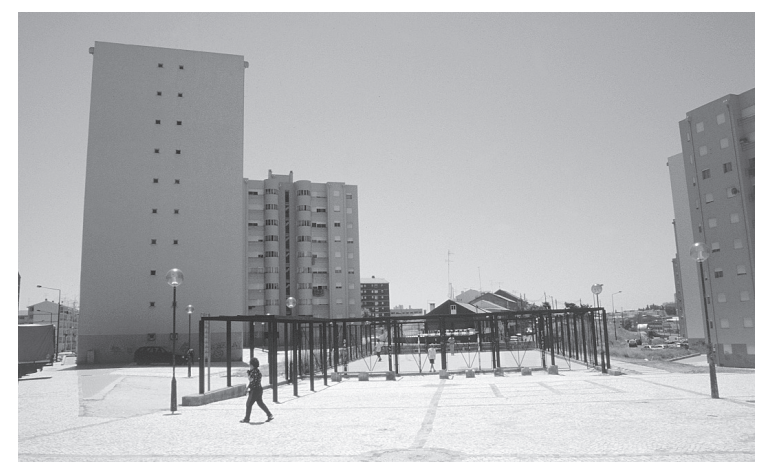

Casal dos Machados. Foto de Alda Gonçalves

Ainda relativamente a esta dimensão (para a qual a ominipresença da droga dá um forte contributo), as estratégias adoptadas nos processos de reconhecimento das imagens negativas traduzem posicionamentos de demarcação que podem definir-se, segundo a tipologia das estratégias de reacção ao estigma de Carmel Camilleri (1996), como estratégias de contestação do estigma e dos actores que no bairro estão envolvidos no processo de estigmatização. Tal contestação faz-se através da adopção de uma atitude racionalizante, de reinterpretação do estigma procurando demonstrar a sua falsidade e desadequação, esvaziando de conteúdo os rótulos e acções difamatórias que procurem fazer de determinados grupos (jovens e minorias étnicas) os responsáveis pelas imagens públicas negativas ("reinterpretação neutralizante"). - Traços visíveis nos três bairros.

"1. Por exemplo, à noite temos assim um rádio estamos assim a ouvir [no espaço relvado do bairro], mesmo se não tivermos assim a ouvir alto, essas "cuscas" vêm à janela, telefonam para a polícia e são capazes de dizer: "Ah! Estão ali uns rapazes negros, estão ali a vender droga, estão ali a fazer aquilo". Só para a policia vir ao bairro para nos tirar dali, é mesmo. São capazes de inventar muitas coisas.

"2. Quando a polícia nos está a agarrar (...) as pessoas mais velhas vêem-nos, vêem e agora tratam-nos como uns bandidos, por uns assassinos, por tudo.

(E14 - Dois jovens, etnia negra, 14 e 18, provenientes de Relógio e Chelas, um é estudante o outro já não estuda, não trabalha, respectivamente - Casal dos Machados)
A ampliação destas imagens negativas é claramente atribuída aos Mass Media que difamam, nomeadamente os "pretos" e os ciganos:

"(...) há pessoas, você sabe muito bem, há famas de droga, famas disto e famas daquilo. Hoje em dia não há bairro ou casa que é da Câmara que não tenha fama.

(...) chamaram o Correio da Manhã, disseram que o bairro era isto, que o bairro era aquilo, que o bairro não sei quê, porquê? Não gostam dos pretos, se for preciso, nessas coisas, (tráfico e consumo de droga] é os brancos que são piores aqui.

(E15 - Imigrante cabo-verdiana, etnia negra, F; 37 anos, filhos jovens e menores, bairro de partida: Moscavide/junto ao antigo matadouro - Casal dos Machados)

Ampliação e empolamentos estes que parecem assumir grande impacto. Através dos media, tais imagens não só se tornam amplamente partilhadas como atingem os bairros globalmente, estigmatizando de forma totalitária os seus moradores. As representações sobre as minorias étnicas, dominantes na sociedade global, interagem nesse processo de estigmatização reforçando-o, sobretudo num contexto social em que, devido à relativa homogeneidade social existente, as relações sociais tendem a etnicizarem-se (Calorigou, 1989).

Outras pesquisas têm revelado dados no mesmo sentido, constatando que "os bairros sociais são, pois, notícia porque são problema. O desemprego, o dia-a-dia descrito como luta pela sobrevivência, a precaridade económica, as actividades desviantes e os comportamentos transgressivos são os elementos seleccionados para o relato noticioso. Estes locais carregariam uma espécie de determinismo social indesejável, que os múltiplos projectos de intervenção, os decisores políticos e os técnicos sociais procurariam minorar. São, na imagem da imprensa, regiões da vida social em corte com a vida colectiva da cidade, sendo os projectos de intervenção uma espécie de ponte entre tal descontinuidade" (Fernandes, 1998: 110).

Projectos, contudo, insuficientes para transformar as representações que a cidade possui destes bairros como "becos sem saída" e que fazem eco no seio dos bairros, "mundos à parte", onde os outros habitantes não entram.

A aparente especificidade do Horta Nova ${ }^{4}$ prende-se, justamente, com a percepção que os

\footnotetext{
${ }^{4}$ Diz-se aparente, porque nos discursos dos entrevistados deste bairro, todas as dimensões e factores que concorrem para a imagem pública negativa, decorrem do estigma da droga, contudo, nos outros dois bairros este é também o estigma presente, embora não tão central nos discursos expressos.
} 
actores têm da visibilidade do fenómeno da droga, nomeadamente pela referência à presença constante de toxicodependentes e traficantes. Aí, todas as conflitualidades e sentimentos de insegurança giram em torno do fenómeno/problema da droga e dos actores que as engendram. De acordo com a informação recolhida, estes actores são estigmatizados no interior do bairro sendo as suas próprias dinâmicas de apropriação do espaço que constituem os elementos estigmatizantes/difamatórios. Assim, quer a difamação na via pública, quer a permanência junto a determinados lotes, associada a actos de vandalismo dirigidos ao edificado e ainda à alegada não participação na limpeza e manutenção das partes comuns dos prédios e a má utilização que fazem dos fogos enquanto titulares, são simultaneamente os factores que traduzem o teor das acusações feitas aos toxicodependentes e as razões das conflitualidades de vizinhança em que se encontram envolvidos.

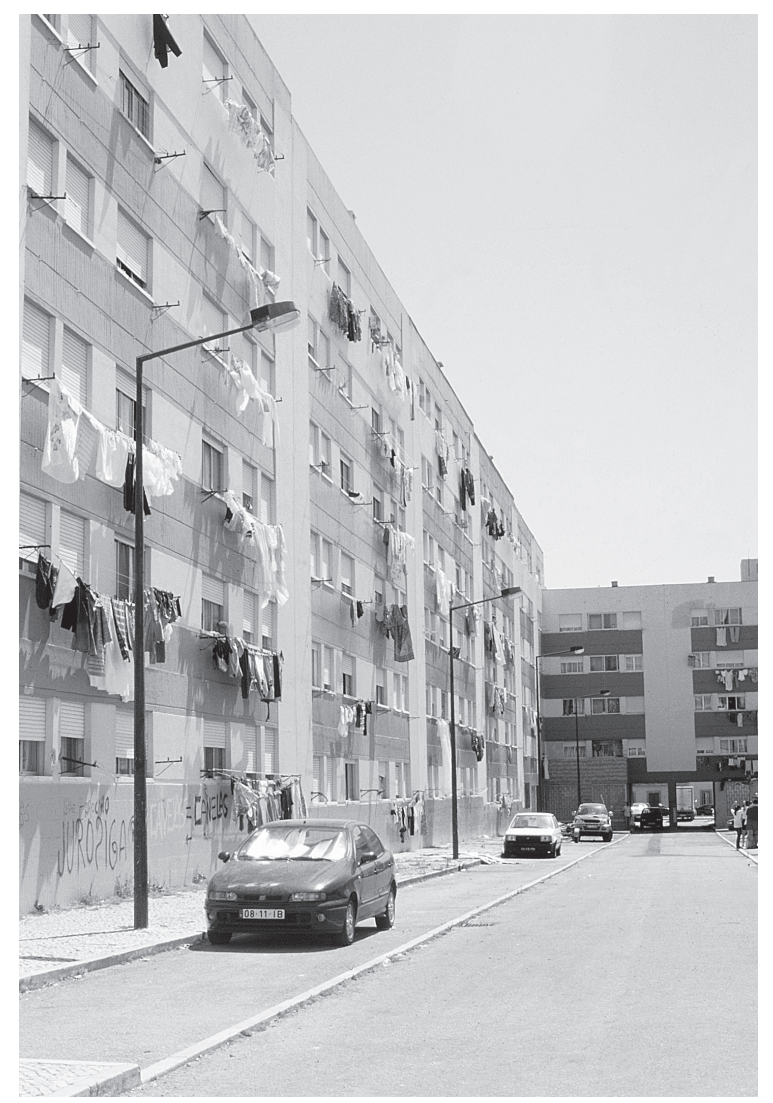

Horta Nova. Foto de Alda Gonçalves

Na perspectiva de alguns dos entrevistados, há que juntar a este outros factores, tais como a composição social e étnica da população residente, as dinâmicas sociais geradas pelas relações de vizinhança e aspectos que se ligam à gestão e manutenção do edificado.

Contudo, ao contrário do que se verificou no Casal dos Machados, em que os posicionamentos face à imagem pública do bairro são diversificados já que alguns dos moradores contestam a má fama do seu bairro, no Horta Nova e no Boavista, observou-se unanimidade nas apreciações, isto é, todos os actores entrevistados (em cada um deles) reconheceram que os seus bairros possuem imagens públicas negativas, essencialmente porque têm "má fama"5, que hoje se encontra fortemente associada ao "problema da droga", às práticas de conflitualidade e de delinquência a que dá origem e os bandos de jovens que as tornam visíveis:

"É péssima, péssima (...) basta eu dizer; eu moro no Bairro da Horta Nova, dizem logo: Aah!... Agora aconteceu-me no hospital, o médico perguntar-me: você onde mora? Eu respondi: no Bairro da Horta Nova..., o médico: Ai... Claro... a maior parte do Bairro da Horta Nova está tudo metido na droga... porque já os conhecem..."

(E5 - Mulher, 28 anos, Toxicodependente em recuperação, etnia africana - Horta Nova)

"Lá está, as pessoas estragam, tem uma má imagem... metade do bairro é bem, metade não presta (...) o que está a dar má imagem para o bairro e para todo o lado é a raça negra."

(E6 - Homem, 32 anos, toxicodependente, residente no bairro desde os 6 anos - Horta Nova)

"Este bairro tem fama de, pronto de ser mau e de haver só droga e não sei quê! Qualquer coisa relaciona-se logo com droga, com violência é logo a primeira coisa com que relacionam este bairro."

(E4, 20 anos, novo residente - Boavista)

"Eu acho que é péssima por aquilo que já ouvi falar (...) assaltos por causa de droga" Boavista)

(E3,16 anos, pais toxicodependentes -

Muitas vezes, a percepção da imagem negativa do bairro no exterior é sentida como estigmatizante, levando os actores a omitir, nas suas relações exteriores, o local de residência ou evitando trazer ao bairro amizades mantidas fora deste contexto (nomeadamente na escola),

${ }^{5}$ Durante gerações, ainda enquanto bairros "antigos" colava-se um estigma de marginalidade, essencialmente pela visibilidade da pobreza e pelas suas deficientes condições de habitabilidade, hoje, assentes noutras causas, o estigma mantém-se após os realojamentos. 
protegendo-se a si próprios duma transposição do estigma para a imagem de si, como se pode observar:

"Em geral digo sempre, Ah, eu moro em Benfica, só quando tenho assim mais confiança é que digo, eu moro no bairro da Boavista"

(E2, 23 anos, inserida em núcleo familiar com ligações a tráfico de droga - Boavista)

Por sua vez, os sentimentos de insegurança aos quais se refere a maioria dos entrevistados, advêm justamente das dimensões que estruturam as imagens negativas dos bairros, como a presença de "drogados" ou "sujeitos suspeitos", os comportamentos delinquentes como "assaltos a moradores", "roubos" de automóveis, a lojas de roupa, armas e outro tipo de objectos, fazendo justiça à tal "má fama" de marginalidade, já referida, que os bairros adquiriram.

Os que reconhecem a insegurança no seu contexto residencial são tanto os que demonstram inquietação e medo como os actores principais responsáveis pelos comportamentos delinquentes:

H: "O que me desagrada é a falta de segurança. Porque aqui às vezes há certo $e$ determinado tipo de problemas. Porque é só pessoas a entrar e a sair e aquelas pessoas que consomem uma pessoa tem que se pôr a pau com eles porque eles podem, a qualquer hora, vir ter com uma pessoa e levarem tudo. Vai dar ao mesmo. E depois há aqui um sujeito... Altas horas da noites, só barulho, andam para trás e para a frente..." dos)

(E11 - família cigana - Casal dos Macha-

1. "Aqui há de tudo. Há ladrões".

[Então e vocês já fizeram isso?]

2. "Nós, já. Fios, bolsas, tudo...

[Então já participastes em assaltos?]

1. "Maioria aqui no bairro, não sei qual é que nunca participou.

Carros, armas, droga... Malas não. Lojas. Lojas de roupa, de armas, de tudo...". cias?]

Vocês não têm medo... que apareçam poli-

1. Medo de quê? Então fugimos. Roubamos carro para quê?

(...) paramos o carro e vamos embora. Pegamos nas coisas e vamos embora. Eles depois se quiserem pegam no carro e vão embora.

(...) antes tinha fama sem proveito!"

(E14: Dois jovens, etnia negra, 14 e 16 anos - Casal dos Machados)

Os que negam que o seu bairro seja inseguro optam por fazer a sua defesa, como nos exemplos seguintes:

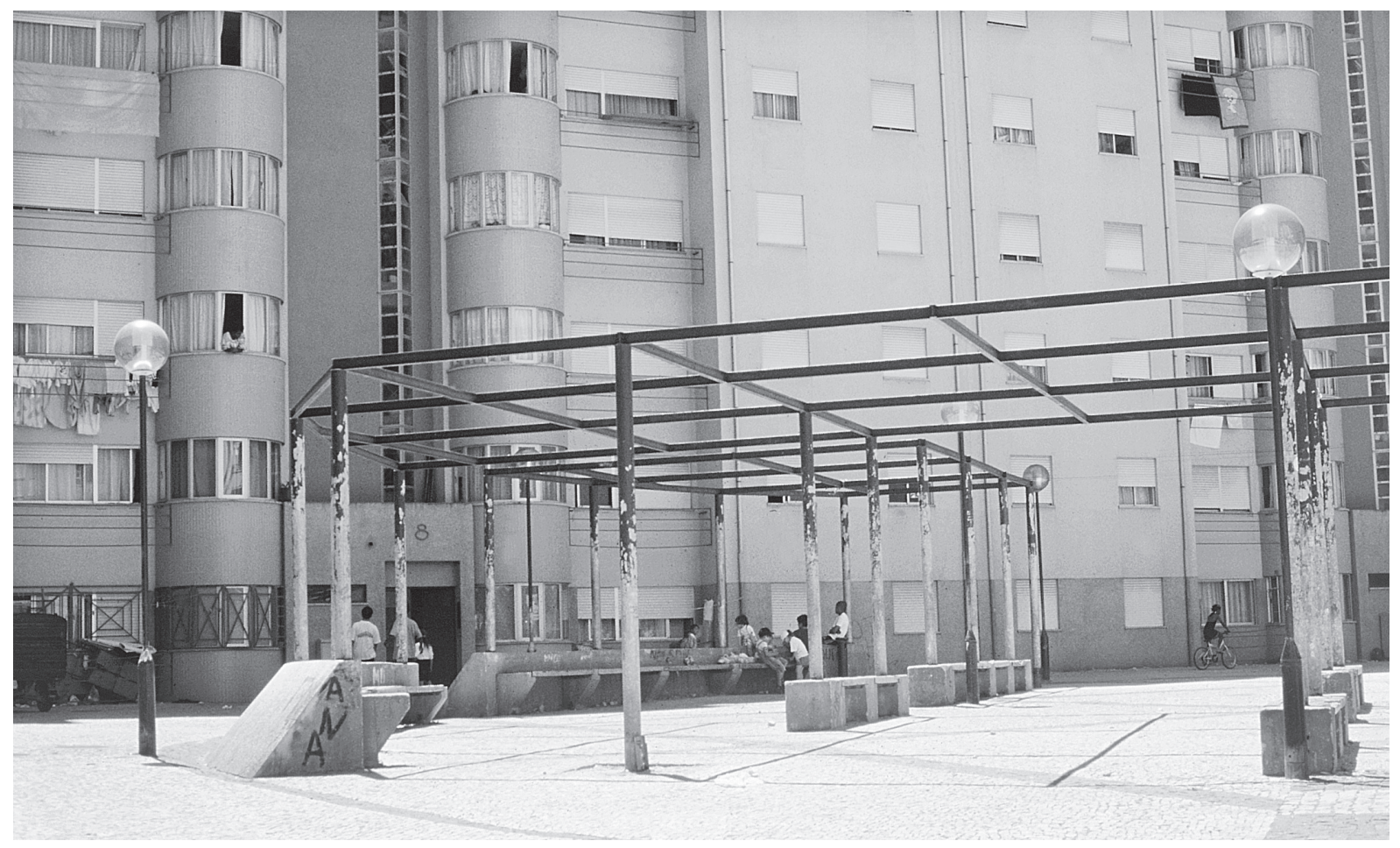

Casal dos Machados. Foto de Alda Gonçalves 
M: "Moramos cá há quase 5 anos. O bairro não é mau (...) não tenho razão de queixa do bairro".

F: É normal.

M: "Não temos razão de queixa".

(E13 - casal envolvido em conflitos de vizinhança - Casal dos Machados)

"Porque eu acho que entre muitos bairros este ainda é um bocado melhor de entre muitos bairros que estão aí. É mais calmo, não há tanta violência como no Bairro Padre Cruz... No Bairro Padre Cruz ainda há mais toxicodepência."

(E5 - Mulher, toxicodependente em recuperação, reside no bairro desde os oito anos Horta Nova)

Todos estes testemunhos acabam por ser reveladores de uma dialéctica constante que se opera entre os moradores e os "seus" contextos de residência, revelando o que Delarue (1991) designa por "consideração de si". Esta "(...) comporta dois aspectos. Uma imagem desvalorizada, que vem menos do bairro em si, que do rótulo que lhe é aplicado (...). O segundo aspecto (...) reside na ligação que esses habitantes têm como o seu bairro: é lá que eles vivem, são conhecidos e reconhecidos" (Cit. por Fernandes, 1998; 113).

\section{Estratégias Identitárias Face ao Estigma dos Bairros: minimização, defesa e exterioridade}

Tendo em conta os objectivos da pesquisa, importava focar sobretudo a relação entre a percepção das imagens públicas dos bairros e as identidades sociais dos seus produtores, isto é, como é que as imagens negativas dos bairros são ou não aceites pelos actores actuando como factores estigmatizantes, ou seja, como é que os actores reagem quando confrontados com esse estigma.

Nesta sequência foram identificadas duas estratégias principais, dicotómicas: uma não contestação da má reputação que recai sobre os toxicodependentes como contribuintes nas imagens negativas, não argumentando a favor do grupo:

"A maior parte do Bairro da Horta Nova está tudo metido na droga, então já os conhecem (...) dão sempre uma imagem muito (...) negativa"

(E5 - Mulher, 28 anos, Toxicodependente, etnia africana. Reside no bairro desde os 8 anos Horta Nova)
"Que seja considerado um bairro de toxicodependentes, é, porque há muitos, como o meu marido, como o $X$, como a $Y$ como o $Z$. Há muitos que já se curaram, outros que estão a tentar a cura e há uns que tentaram e caíram outra vez... porque a gente também devia de ter um centro como o Bairro Padre Cruz de reabilitação de drogados..., que viessem várias pessoas falar, o poder do diálogo"

(E9 - Mulher, 33 anos, nega o consumo de narcóticos, companheira de dealer local - Horta Nova)

Outra, apesar do reconhecimento da imagem negativa, contestando a reputação atribuída ao grupo de pares, encontrando explicações exteriores para o problema:

"Em certa parte tem, em certa parte tem por... mas não é má fama de dizer: "ah, aquilo é só drogados" é mais por causa da alcovitisse, as pessoas estão sempre a arranjar confusões. Em vez de olharem para a vida delas olham para a vida dos outros."

(E10 - Homem, 23 anos, Toxicodependente, nascido no bairro - Horta Nova)

De facto, as estratégias identitárias encetadas face ao impacto de imagens negativas, são demonstrativas de que alguns actores percepcionam o jogo interactivo e estigmatizante entre a imagem de si e a imagem negativa que naqueles contextos sociais se desenvolve e reproduz.

Outros efectuam um "reconhecimento por minimização da imagem pública negativa" fundamentado na optimização da imagem captada a partir da actualidade do bairro, defendendo uma evolução positiva daquela imagem negativa com ramificações no passado e confrontando-a com as representações colectivas dos bairros degradados de má fama. Isto é, a opção é de defesa do seu bairro, ainda que reconhecendo os traços de algumas negatividades:

"Isso já foi muito pior do que o que está (...) Isso é uma gota no oceano. Se formos a falar de Buraca ou de 18 de Maio (...)".

(E17 - Dois jovens, etnia negra, de 22 e 24 anos, bairro de partida: Relógio e Av. P. Cruz, trabalhadores - Casal dos Machados)

Outros ainda salientam o facto de a fama do bairro ser propositadamente construída por determinados moradores que encontram nos elementos de desvalorização, formas alternativas de construção identitária. 
"Já ouvi alguns que estavam a falar do bairro de S. ${ }^{\text {ta }}$ Cruz chegou lá um bacano "olha vamos ao bairro da Boavista dizem que vai haver lá um baile" Quem eu? Só se for com a roupa das obras porque se for com a minha roupa roubam-me tudo, venho nu, mas eu nunca vi fazerem isso, nem nunca ouvi, nem nunca deu para entender isso".

(E3, jovem de 16 anos, nascida no bairro, pais toxicodependentes - Boavista)

"Pronto a fama que se ganhou lá fora foi, por exemplo, basta bater num aqui do bairro, arranja-se logo aqui um grupo e vai-se logo ao bairro dos outros bater, pronto e talvez por causa disso, começaram a ganhar medo deste bairro, começaram a ter fama de violência e não sei quê. (mas as pessoas que cá moram são mais violentas?)

$R:$ não, são violentas iguais aos outros bairros, só que querem parecer mais violentas que os outros bairros (...) essas pessoas que fazem isso [hostilizam as pessoas que vêm de fora] querem que o bairro tenha essa fama, mas no fundo se formos, os que fazem isso é um grupo de putos"

(E4, jovem de 20 anos, vindo do bairro da Serafina-Boavista).

Estrategicamente, estes actores minimizam o impacto daquela imagem publicamente divulgada, enfatizando a actualidade do bairro numa perspectiva de normalidade, relativizando-a face ao quotidiano de outros bairros socialmente semelhantes: "já foi ou podia ser pior". Embora não negando as atribuições feitas aos bairros, não as assumem com o empolamento e generalização que a fonte estigmatizadora da imagem pública lhes confere, uma vez que não reflectem a sua própria imagem ou não se adequam às expectativas que essencialmente projectam sobre o seu local de residência.

Um "não reconhecimento da imagem pública negativa" é assumido por aqueles que optam por fazer a defesa do seu bairro e, neste sentido, revelam os critérios pelos quais o fazem. A imagem que os actores formulam é baseada numa avaliação estética e arquitectónica do edificado e do bairro em si:

M: "Eles [os amigos de fora do bairro] dizem que aqui ainda é melhor que Chelas. É outro ambiente, é... gostam mais do sítio, que é muito melhor. Estar ao pé da Expô 98..."

M: "O tipo das casas também é outro, é (...) São, muito melhores..."
(E13 - Família portuguesa, M: 36 anos, empregada de restaurante; H: 37 anos, desempregado - Casal dos Machados)

A análise categorial permitiu compreender quais as variáveis que fundamentam a diferenciação destes posicionamentos estratégicos adoptados pelos actores ao nível da percepção da imagem pública, revelando que a percepção do estigma associado às imagens negativas não é vivido da mesma forma pelos actores que assumem diferentes posicionamentos. $\mathrm{O}$ primeiro grupo autopercepciona-se como elemento visado na responsabilização colectiva sobre a produção de imagens públicas negativas (responsabilização das minorias étnicas e dos jovens, nomeadamente a visibilidade das suas práticas no espaço do bairro e, sobretudo para os jovens entrevistados, o quotidiano do bairro representa um espaço de interiorização da ideia de serem os continuadores da má fama do bairro). $\mathrm{O}$ segundo grupo evita ser alvo desse processo de responsabilização, situando o seu discurso fora do quadro de relações conflituais, optando por centrar o discurso em variáveis urbanísticas, que entende serem elementos que conferem alguma positividade à imagem do bairro.

A reprodução da fama dos bairros reflecte, antes de mais, o fechamento das relações sociais sobre si mesmas, reforçando o processo de guetização dos mesmos.

Neste contexto, é possível admitir que, para determinados grupos ainda que minotitários, as imagens públicas negativas não só não são rejeitadas, como são cultivadas, grupos esses que consideram os actos delinquentes e os comportamentos desviantes como símbolos de bravura e poder em vez de atributos de desqualificação.

A análise de uma entrevista colectiva permitiu concluir que determinados comportamentos (de pequena delinquência ou mesmo violência), pelo menos no seio do grupo de jovens, constituem, simultaneamente, reacção a formas de estigmatização que lhes chegam do exterior e elementos de afirmação que, em círculo vicioso, contribuem para a (re)produção das imagens negativas dos contextos residenciais. No decurso desta entrevista colectiva com jovens, alguns dos quais já integraram bandos com má reputação no bairro, observou-se claramente essa atitude dupla de um reconhecimento da negatividade das imagens públicas, associada a uma estratégia de conversão dessa imagem num capital próprio positivo, como se havia referido. Observe-se o seguinte fragmento: 
"P: que tipo de pessoas é que eram roubadas, vocês escolhiam-nas a dedo? Como é que era?

Interlocutor $2-A$ maior parte é gordos $e$ quequinhos.

Pergunta: Porquê gordos e quequinhos?

Interlocutor 1 - Vejo um relógio, gosto, roubo, uma pulseira, gosto, roubo, uns ténis, gosto, roubo e outras vezes é porque dá raiva... vêm aquele miúdo e dá raiva essa pessoa... só apetece chegar ao pé dele e pô-lo todo nú... raiva?

P.: Porque é que achas que certas pessoas dão

Interlocutor $4-e u$ sei essa..., é porque às vezes passa um, que se arma em bom, vem todo betinho, a gente chega lá e diz: dá cá isso e rouba- o todo, é por causa disso, porque ele arma-se em bom, pensa que é campeão...

Interlocutor 1 - Só por causa dos pais deles que ganham mais dinheiro do que o nosso, pensam que são pessoas maiores, são os donos do mundo e só apetece mesmo é ir lá apertar-lhe o pescoço (gesto de raiva e risos).

Intervenção do entrevistador: Mas eles não têm culpa dos pais serem assim...

Interlocutor 1: Não têm culpa mas podem controlar mais as suas atitudes, é por causa disso é que são roubados"

(Entrevista Colectiva - Boavista)

Este excerto vem colocar no centro da análise, simultaneamente uma preocupação e uma constatação: a de que a delinquência resulta de uma estratégia de resposta a formas de estigmatização que o grupo sente do exterior, apropriando-se, através dos actos delinquentes, de elementos que transforma em factores valorizadores da sua identidade e do seu estatuto (coragem, bravura, capacidade de liderança, etc.). Para estes jovens, a fama do bairro é apreendida através duma dualidade de critérios: por um lado, é plenamente assumida e cultivada, por outro, defende-se o bairro comparando-o com outros bairros sociais e afirmando que o seu "não é melhor nem pior do que os outros". O que se joga nesta defesa do bairro é também a defesa da própria identidade pessoal e colectiva.

\section{Actores, Identidades e Projectos: a resignação ao estigma}

"As pessoas têm as suas ideias convicções, representações do mundo solidamente alicerçadas nas suas estruturas cognitivas. A novidade surge aos sujeitos como estranha e dificilmente altera essa visão do mundo construída ao longo de toda a história de vida de um indivíduo. Mesmo que se ouça outra opinião, com os tempos, apaga-se e perduram as mesmas imagens e percepções das pessoas e das coisas."

Vieira, Ricardo (1999), Ser Igual, Ser Diferente - Encruzilhadas da Identidade, Profedições, p. 28.

As identidades assumidas e expressas pelos actores entrevistados - que, não pode esquecer-se, são responsabilizados e responsáveis (assumidos, em vários casos) pelas imagens negativas dos respectivos bairros - constroem-se e são fortemente marcadas pelo confronto com identidades prescritas claramente percebidas como negativas. Trata-se, em geral, de actores cujas identidades se encontram, por relação ao estigma dos bairros, elas próprias estigmatizadas.

"Uma pessoa quando está a consumir drogas é como se estivesse perdida no tempo, É como se a gente não existisse porque a gente só vive para aquilo, acorda-se de manhã a pensar naquilo... uma pessoa acorda, mal se alevanta só pensa é onde vai arranjar dinheiro para aquilo, uma pessoa não quer saber dos filhos, não quer saber da mãe, não quer saber do pai, não quer saber de nada (...) tornamo-nos egoístas!... só queremos é para nós"

(E5 - Mulher, 28 anos, assume-se em recuperação, angolana - Horta Nova )

"Um toxicodependente é um lixo, um trapo para eles não vale nada e não tem direito a nada"

(E6 - Homem, 32 anos, reside no bairro desde os 6 anos - Horta Nova)

"Há situações em que interfere (...) eu já vi montes de situações em que dizem assim, há os pais são toxicodependentes, a gente não quer filhos de toxicodependentes eu fico assim a olhar para eles: poça! se soubessem que eu também sou, ía a ver o que é que me faziam."

(E3 - sexo feminino, 16 anos, nascida no bairro, pais toxicodependentes - Boavista)

"Ela, mora aqui no bairro (..) e a minha mãe ligou-se com ela entretanto fizeram umas ligações, passava a vida a andar com eles (...) com aquela família. Toda a gente sabia e comentava... até o D. inclusive ele já me conhecia e via-me: "olha a H. é da batida do pó"

[P: quando a vossa família estava conotada no bairro com a família dos traficantes como é que era vista no bairro?] 
R. Foi mau porque eu estava, pelo bairro, a ser vista por outra pessoa, aquilo que eu não era realmente (...)"

(E2 - 23 anos, filha de mulher presa por tráfico de droga - Boavista )

Contudo, não é apenas a toxicodependência que marca a estigmatização identitária, ela é marcada também pela precaridade das condições de existência:

"Agora, a mim não me faz diferença o que é que elas pensam, o que é que elas dizem. Eu só digo é que elas não pensem muito, que às vezes lhes pode acontecer a mesma coisa. Porque têm filhos.

A minha vida é muito complicada... e prontos é cinco filhos, marido sem trabalhar, eu sem trabalhar (...) torna-se complicado... não é só as vizinhas ajudarem-me que se consegue resolver (...). E sinto-me triste, porque, "prontos"... há alturas em que não há "comer", há miséria, "prontos", é... é isto...

[E o que é que faz para... o que é que sente em relação a isso?]:

Eu, sinto-me mal. Às vezes sinto-me sem forças para poder lutar..., para criar os meus filhos, para não lhes faltar nada nas alturas que eu não consigo..."

(E4 - F, 31 anos, desempregada, marido toxicodependente - Casal dos Macados)

Mesmo aqueles que reagem ao estigma e o ocultam, aqueles que encetam estratégias de minimização dos referentes depreciativos, indiciam-no de forma latente aos discursos.

"Por acaso, comigo, nunca aconteceu isso [ser marginalizada pelo facto dos pais serem toxicodependentes] porque o pessoal que eu conheço é quase todo aqui do bairro, andam quase todos na minha escola, mas mesmo os que não andam, por acaso não sabem assim mais ou menos (...) quando estou com os meus amigos, não (falo disso) temos outras coisas para falar, sobre amigos, os namorados e montes de coisas"

(E3 - sexo feminino, 16 anos, nascida no bairro, pais toxicodependentes - Boavista)

"Eu não, eu não fumo nada, só uma ganza de vez em quando e é quando tenho dores de dentes, eu não tenho coiso de dizer (...) porque eu vejo o sofrimento das pessoas, depois olho para os meus irmãos, que eu tenho dois irmãos (..) eu sei aquilo que eles fazem que eu já levei à conta disso"

(E9 - Mulher, 33 anos, companheira de toxicodependente e pequeno dealer - Horta Nova)
Os maiores condicionalismos subjacentes à capacidade de definição de projectos de vida, por boa parte destes actores que vêm demonstrando identidades sociais/residenciais estigmatizadas, no contexto dos bairros sociais em análise, parecem ser a toxicodependência, a seropositividade e, sobretudo no Horta Nova e no Boavista, a percepção do impacto social da diversidade étnica.

A forma como os entrevistados reflectem ou "re-apresentam o seu passado" (a sua infância) oscila entre a exaltação desse período, como algo com o qual o actor se identifica e que contrasta fortemente com a situação presente, e a tentativa de encontrar na vivência passada (e sobretudo no plano afectivo) a explicação para uma trajectória de vida, muitas vezes, assumida como fracassada.

Nesta sequência, observando as imagens que alguns dos actores transmitem dos contextos sociais da sua infância, ressaltam os traços insistentes de precariedade, quer habitacional ("barracas de madeira"), quer escolar ("medo... da escola") - "gostava de ir estudar porque custa muito uma pessoa não saber ler". O próprio contexto de carências económicas manifesta-se na transição de uma ruptura escolar precoce para o início da vida adulta, trabalhando pela sobrevivência da família de origem. Embora de forma não linear, a precariedade material tende, em muitas situações, para a precariedade das relações familiares e/ou escolares conduzindo a confrontos precoces com a violência ou agressividade física e moral. De facto, estes actores revelam uma infância traumática nas relações com os adultos (nomeadamente começando pelos contextos familiares), evocando experiências de alcoolismo e repressão por parte de vigilantes nas escolas e de polícias nas zonas residenciais. São estes os personagens que ensombram os seus imaginários e que desde cedo obrigaram a estratégias identitárias simultaneamente defensivas e reactivas.

Em relação aos projectos de vida, como se vem observando ao longo de todo o texto, uma das categorias fundamentais que os condiciona é o facto de os actores assumirem ou não a toxicodependência, elemento estruturador de diferentes visões quer do presente quer do futuro.

Os actores que assumem a toxicodependência reconhecem a centralidade e a presença de uma rotina da droga, não demonstrando capacidade de definição de qualquer projecto de vida ou condicionando-o a um tratamento prévio, capaz de afastar o vício, sendo, assim, a droga a justificação para a ausência ou adiamento de projectos e sonhos. Na expressão de um toxicode- 
pendente que viveu recentemente um processo de reabilitação "a droga é uma paragem no tempo".

A seropositividade é outro factor limitativo da possibilidade de definição de projectos de vida.

"Acho que não tenho Futuro nenhum, (...) ou cai algum anjo do céu que me tire daqui"

(E12 - Homem, 29 anos, portador de HIV, conflitualidade de vizinhança - Horta Nova)

"O meu desejo é voltar a ter novamente, nunca a mesma mulher, uma vida organizada como eu tinha aí à uns 7 anos atrás, quero ter a minha vida normal, como outro casal qualquer, pai de filhos, ter respeito em casa, não faltar nada em casa aos filhos e não ter zaragatas com a mulher em casa... mas só posso falar disso (do meu Projecto de vida) quando vier lá de cima pra baixo (local onde pretende fazer uma cura de desintoxicação) eu não gosto de falar antas de tempo...

P. Porquê? O seu projecto actual é ir consumir droga?

$R$. Exacto, neste momento é isso "

(E6 - Homem, 32 anos, reside no bairro desde os 6 anos, toxicodependente - Horta Nova)

Os que não assumem a toxicodependência enunciam ora questões de saúde, ora a vulnerabilidade da sua condição social e económica como factores limitativos da definição de projectos de vida mais ambiciosos numa clara consciência da limitada gama de oportunidades, balizadas pelos baixos níveis de escolaridade, pelas baixas ou inexistentes qualificações profissionais e, muitas vezes ainda, pela diversidade de recursos culturais e competências sociais que comprometem quaisquer ambições de elevação dos seus estatutos sociais.

[O que é que tu gostarias de fazer como profissão?]

"Isso não sei. Só o futuro o dirá.

[Não tens um projecto... o que gostarias de ser?]

"Não. Só o futuro o dirá.

(Com desejos de gravar um disco mas...) Portugal é pregado, não há guitos para lançar um"

(E16 - jovem de origem africana, desempregado - Casal dos Machados)

"Não faço planos, que dá azar, eu quero é que isto se me cure (doença de pele) o mais depressa possível que é para arranjar trabalho, para sair outra vez daqui para fora, já estou farta deste bairro (...).

Mas eu tenho esperanças de mudar, porque eu quando começo a trabalhar compro de tudo quanto haja, não é, vou para a frente, ganho energia, dá-me força, de ver os meus filhos, eu posso andar toda suja, mas os meus filhos andam sempre arranjadinhos."

(E9 - Nega o consumo de narcóticos, o marido é toxicodependente e pequeno traficante. Conflitualidade de Vizinhança - Horta Nova)

A este fragmento discursivo, encontra-se subjacente uma preocupação, que é comum a mais alguns entrevistados residentes nos bairros, bem como a técnicos: a percepção da visibilidade dos espaços que possuem a reputação de "lugares de drogados" ou "territórios psicotrópicos", na designação adoptada por Fernandes (1998) e as suas consequências sobre um elevado número de crianças e jovens adolescentes expostos quer a essa visibilidade, quer ao contacto precoce com as rotinas da droga, observáveis no quotidiano de quem os rodeia, em contextos onde a "consideração de si" resulta na expressão de auto-imagens desvalorizadas e negativas.

Por seu lado, a questão da habitação e da assinalada degradação do edificado, encontram-se presentes na produção e reprodução de imagens públicas negativas, possuindo uma relação estreita com esses "territórios psicotrópicos", já que, como se observou, interferem decisivamente na definição de sentimentos de pertença aos bairros.

Alguns relatos biográficos indiciam ainda que a origem étnica, aliada ao desejo de mobilidade social, é estruturadora de um quadro de estratégias no sentido de dar resposta aos constrangimentos que a sociedade propõe aos actores em termos de dinâmicas de exclusão/ /inclusão social, especialmente no Casal dos Machados.

Uma forte presença étnica encontra-se sobrerepresentada neste bairro, tornando-se num factor fundamental de implicações consideráveis nas dinâmicas sociais locais.

A real importância daquele factor contribui para o entendimento não só da subtileza da rede de conflitualidades, que se enuncia como a forma privilegiada de relações sociais existentes nos contextos residenciais, como dos projectos de vida que se constroem, por intermédio de estratégias que respondem a prescrições identitárias de estigmatização social dos seus bairros. 
Quando a ausência dos valores de base marca as relações jovem/adulto, ou se observam dificuldades de comunicação que caminham a par com a falta de alternativas de ocupação juvenil, a acumulação de decepções, a frustração e incapacidade de fazer face a um conjunto de dificuldades em crescendo, ajudam a criar condições para a adopção de comportamentos de marginalidade, passando a iniciação pela delinquência juvenil que, por sua vez, representa o reforço reprodutivo dos sentimentos de insegurança e de imagens públicas negativas face aos bairros.

$\mathrm{Na}$ sequência da complexidade do impacto do factor étnico, considerando as características de um conjunto de actores, a insatisfação de viver no bairro, quer pelo estigma da delinquência ou "difamação" por droga, quer pelo estigma da cor como sinal de pertença étnico-cultural, quer ainda pelo sentimento de insegurança manifesto, raras são as vezes em que aquele factor não intervém na composição de variáveis explicativas de tais fenómenos, com efeito multiplicador para as relações de conflitualidade que envolvem a vizinhança e, embora observáveis também no Horta Nova, se salientam especialmente no Casal dos Machados ${ }^{6}$.

Atendendo aos contornos actuais da etnicidade, as dinâmicas inter-étnicas vêm assumindo e que, segundo Oliver Roy (1993), podem considerar-se sinais de uma Segunda Identidade Étnica emergente que esses jovens, descendentes de imigrantes de origem negro-africana e não só, possuem. Trata-se de uma minoria de "segunda geração" que habita os "bairros em risco", conhecedora do insucesso escolar e do desem- prego e que se encontra à mercê da pequena delinquência e da violência. O que é de notar é que estes jovens são reconhecidos e se reconhecem como pertencentes a uma etnia e se opõem à sociedade com a qual estabelecem vínculos de nascimento mas não reconhecem uma relação de pertença e de afectividade e, portanto, de não identificação étnica.

Todos estes ingredientes entrecruzados, tendo sempre como pano de fundo a crescente visibilidade da droga (tráfico e/ou consumo), tornam visível a complexidade das relações sociais locais, complexidade assente em formas várias de segregação social e territorial subjacente aos bairros em análise e são, objectivamente, condicionadores da capacidade de definição de projectos de vida.

Tal clima de segregação e também de desconfiança, não compromete apenas as relações entre a população residente e as instituições locais, mas remete igualmente para uma postura sociocultural que a população mais desfavorecida tende a adoptar e que se prende com as representações que possui de si mesma (a "consideração de si"), dos seus papéis e dos direitos e deveres que regulam a sua relação com a sociedade civil e o Estado (e, em última instância, a sua inserção/ exclusão social). Esta postura consiste num obstáculo ao aprofundamento de outras formas de exercício da cidadania em contextos sociais dominados pelas vulnerabilidades sociais e económicas.

O esquema da página seguinte, permite sintetizar toda a complexidade que se pretendeu explicitar.

\footnotetext{
${ }^{6}$ Recorde-se que, no Boavista a especificidade das conflitualidades se centra essencialmente nas formas de apropriação dos espaços públicos efectivados por bandas de jovens e na clivagem entre novos e "velhos" residentes, pois os novos residentes que introduziram elementos de tensão não só pelo acesso à habitação a que outros não tiveram direito (e continuam a morar no bairro, em casas de alvenaria) mas também pela alteração que provocaram na estrutura social: apresentam-se como desconhecidos provenientes de outros bairros com uma imagem tão ou mais negativa que o bairro de acolhimento.
} 
Esquema 3 - Categorias Intervenientes nas Identidades e (In)Definição de Projectos de Vida

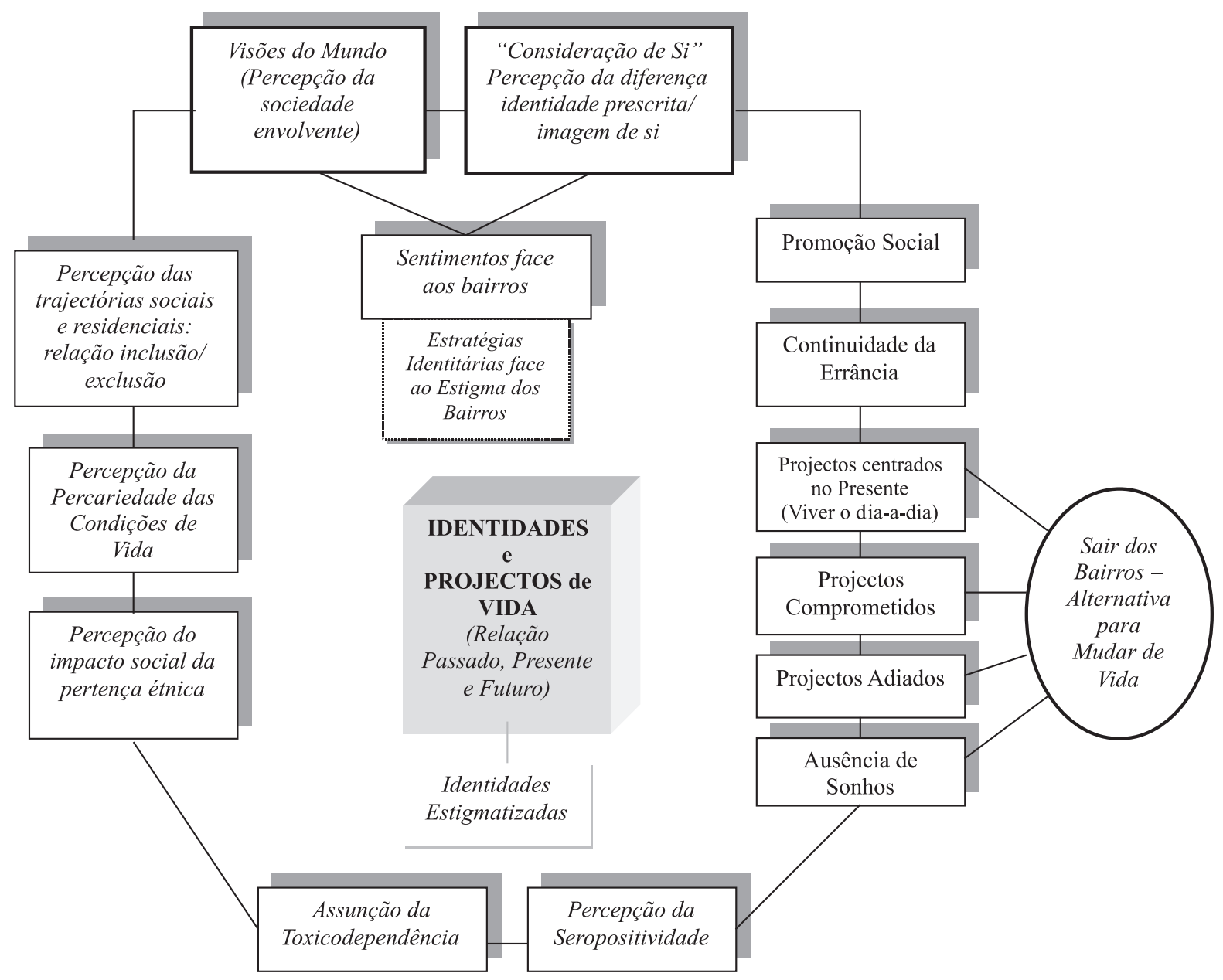

\section{Síntese Conclusiva}

Actores, imagens públicas e identidades são elementos que, nestes bairros sociais, se jogam num tabuleiro tridimensional: a droga, as conflitualidades e os bandos de jovens. São categorias centrais de discursos heterogéneos de actores residentes que, de formas diversas, apreendem, (re)constroem e representam, para si, as imagens que reconhecem negativas dos seus bairros para, de seguida, as exteriorizarem e a elas reagirem, imagens profundamente enraizadas que os realojamentos não souberam ou não puderam apagar.

A droga - elemento visível e transversal aos três bairros -, a segregação social e residencial num deles, a diversidade étnica de muitas famílias vindas de outros bairros, de outros contextos residenciais, também marcados pela precariedade e pela pobreza noutro, e os traços de uma juventude "ruidosa", reactiva e muito visível, porque ocupa e apropria os espaços públicos aí jogando as suas "contra-regras" e impondo as suas contra-culturas, conotadas com a marginalidade, parecem ser causas e, num teimoso círculo vicioso, consequências intrincadas que marcam os ritmos e as cadências da realidade quotidiana destes actores sociais.

As variáveis que (no conjunto dos bairros) se cruzam com estes referentes discursivos tornados dimensões primordiais de análise, para dar uma ideia aproximada da complexa realidade com a qual se confrontam os residentes produtores de imagens e os residentes receptores/ reprodutores, são essencialmente o sexo, a idade, o tempo de residência no bairro, a vivência dos realojamentos, a densidade populacional, a diversidade étnica, bem como a inserção na malha urbana e a conservação e manutenção do edificado. 
Apesar das suas histórias e trajectórias serem diversas, estes bairros têm muito em comum, transportam consigo o peso de uma má fama secular, que hoje se mantém e os estigmatiza, assim como aos seus residentes; uma população que genericamente partilha de idênticas situações de pobreza (porque as casas não trouxeram consigo o emprego, formação escolar e/ou profissional, acesso à cultura ou o respeito pela ambiência do bairro) e boa parte das famílias residentes confrontam-se ou já se confrontaram com situações de exclusão social (pelos níveis de desestruturação, pelas ligações à droga - tráfico e/ ou consumo, pelo racismo e pela intolerância); apesar das preocupações urbanísticas, partilham uma imagem estética formatada, facilmente reconhecível como bairro social e após os realojamentos mantiveram as mesmas designações que no exterior já eram signos referentes de pobreza, miséria e precariedade. Em todos eles há indícios de "espaços psicotrópicos", definidos como "lugares urbanos onde é visível a ocorrência de actividades ligadas às drogas, desde o comércio ao consumo, passando pelo convívio e pela ocupação do tempo, tendo como elemento importante do encontro as drogas

\section{Referências Bibliográficas}

AAVV, (1996), Observatório de Habitação (fase 5): Satisfação Residencial, Imagens e Identidades, Lisboa, CET.

AAVV (1998), Observatório de Habitação (fase 6): Processos de Constituição de Imagens Públicas, Dinâmicas de Conflitualidade e (In)Segurança, Lisboa, CET.

AAVV (2001), "Os Ciganos Vistos Pelos Outros", Cidades.Comunidades e Territórios, n. ${ }^{\circ}$ 2, Lisboa, CET/ ISCTE.

BRUN, J., RHEIN, C. (Ed.), (1994), La Ségregation dans la ville. Concepts et mesures, Paris, L'Harmattan.

CAMILLERI, C. (1996), "Stigmatization et stratégies identitaires", in HAUMONT, N., La Ville: ilegais." (Fernandes, 1998:32)

Estes territórios ou lugares "psicotrópicos" são os signos do receio, do medo e da insegurança, para quem os não frequenta e contribuiram para transformar as dinâmicas sociais assentes em relações de solidariedade e vizinhança, em dinâmicas sociais defensivas fundadas na desconfiança e na conflitualidade.

Contudo, boa parte dos residentes mantêm-se fiéis aliados e, ainda que reconhecendo unanimente a má fama e a imagem negativa, mesmos os produtores de comportamentos que a perpetuam, defendem-nos com convicção como se se defendessem a si próprios. Reagem, pois, ao estigma que, por via da identidade residencial atingida, se cola às suas identidades pessoais e sociais.

De facto, estes entrevistados são actores cujas oportunidades, projectos de vida e identidades e se encontram irremediavelmente ligadas às imagens públicas negativas dos seus contextos residenciais. As suas identidades estigmatizadas, as dificuldades de reflexão sobre o presente e a incapacidade de definição de caminhos de futuro são provas irrefutáveis de tais ligações.

agrégation et ségregation sociales, Paris, L'Harmattan

FERNANDES, L. (1998), O Sítio das Drogas, Lisboa, Editorial Notícias.

FREITAS, J. (1994), "Os Paradoxos do Realojamento", Sociedade e Território, n. ${ }^{\circ}$ 20, Porto, Afrontamento.

MADEC, A. ; MURAD, N. (1998) Cidadania e Políticas Sociais, Lisboa, Instituto Piaget.

PINTO, T. (1994), "Apropriação dos espaços em bairros sociais: o gosto pela casa e o desgosto pelo bairro", Sociedade e Território, n. ${ }^{\circ}$ 20, Porto, Afrontamento.

TABOADA-LEONETTI (1990), "Stratégies Identitaires et Minorités: Le Point de Vue du Sociologue", in Stratégies Identitaires, Paris, Puf.

VIEIRA, R. (1999) Ser Igual, Ser Diferente Encruzilhadas da Identidade, Leiria, Profedições. 